\title{
Identification of Two Pathogenic Avian Mycoplasmas as Strains of Mycoplasma pullorum
}

\author{
PIERRE-YVES MOALIC, ${ }^{1}$ ISABELLE KEMPF ${ }^{1}$ FABIENNE GESBERT, ${ }^{1}$ AND FRÉDÉRIC LAIGRET ${ }^{2 *}$ \\ Unité de Recherches Mycoplasmologie-Bactériologie, Centre Nationale d'Etudes Vétérinaires et Alimentaires, \\ Ploufragan Zoopole, 22440 Ploufragan, ${ }^{1}$ and Laboratoire de Biologie Cellulaire et Moléculaire, \\ Institut National de la Recherche Agronomique et Université de Bordeaux II,
}

33883 Villenave d'Ornon Cedex, ${ }^{2}$ France

\begin{abstract}
Two mycoplasma strains were isolated from dead turkey embryos. Growth properties, biochemical and serological characteristics, and protein profiles indicated that these strains were closely related to Mycoplasma pullorum CKK $^{\mathrm{T}}$ ( $\mathrm{T}=$ type strain). This was confirmed by $16 \mathrm{~S}$ rRNA sequence analysis, and the phylogenetic position of $M$. pullorum was established. Pathogenicity studies showed that the two strains, as well as $M$. pullorum CKK $^{\mathrm{T}}$, induced a statistically significant level of mortality after inoculation into chicken embryos.
\end{abstract}

Mycoplasma gallisepticum, Mycoplasma synoviae, Mycoplasma meleagridis, and Mycoplasma iowae are known to be pathogenic for turkeys $(13,34)$. Other species, such as Mycoplasma cloacale, Mycoplasma gallinaceum, Mycoplasma gallopavonis, Mycoplasma iners, and Mycoplasma lipofaciens, may be isolated from turkeys but have not been clearly associated with pathogenicity. Recently, we isolated two mycoplasma strains, one from a dead turkey embryo found in a specific-pathogen-free (SPF) flock (strain 94254) and one from a dead turkey embryo which occurred in a field flock (strain 95098GC). In these two flocks, the hatchability percentages (average, $87.7 \%$ ) were lower than the expected values (more than 95\%). Preliminary experiments indicated that the mycoplasma strains did not seem to be related to any of the species mentioned above but resembled Mycoplasma pullorum, a species not known to be pathogenic for turkeys (14). In order to determine if the two newly isolated strains belonged to the species $M$. pullorum, we analyzed their cultural, biochemical, and serologic properties and compared them to the type strain of $M$. pullorum, strain CKK. We also evaluated the pathogenicities of the three strains for chicken and turkey embryos. To confirm our results and because the phylogenetic position of $M$. pullorum has not been established previously, we analyzed the $16 \mathrm{~S}$ rRNA sequences of the three strains.

\section{MATERIALS AND METHODS}

Mycoplasma strains. The following strains were used: Mycoplasma anatis $1340^{\mathrm{T}}\left(=\right.$ ATCC $\left.25524^{\mathrm{T}}\right)(\mathrm{T}=$ type strain $)$, Mycoplasma columbinum MMP-1 $\left(=\right.$ ATCC $\left.29257^{\mathrm{T}}\right)$, M. gallinaceum $\mathrm{DD}^{\mathrm{T}}\left(=\right.$ ATCC $\left.33350^{\mathrm{T}}\right)$, Mycoplasma galli narum PG16 ${ }^{\mathrm{T}}\left(=\right.$ ATCC $\left.19708^{\mathrm{T}}\right), M$. gallopavonis WR1 ${ }^{\mathrm{T}}\left(=\mathrm{ATCC} 33551^{\mathrm{T}}\right)$ M. gallisepticum ATCC 15302 , Mycoplasma glycophilum $486^{\mathrm{T}}\left(=\mathrm{ATCC} 35277^{\mathrm{T}}\right)$, $M$. iowae $695^{\mathrm{T}}\left(=\mathrm{ATCC} 33552^{\mathrm{T}}\right), M$. pullorum $\mathrm{CKK}^{\mathrm{T}}\left(=\mathrm{ATCC} 33553^{\mathrm{T}}\right), M$. synoviae WVU $1853^{\mathrm{T}}\left(=\mathrm{ATCC} 25204^{\mathrm{T}}\right)$, and $M$. meleagridis $17529^{\mathrm{T}}(=\mathrm{ATCC}$ $25294^{\mathrm{T}}$ ). One additional mycoplasma field strain, strain 90000 , which is serologically related to $M$. pullorum and was isolated from pheasant trachea (17), was included. Mycoplasmas were grown in FM4 medium supplemented with yeast extract and pig serum (11).

Isolation procedure. Strain 94254 was isolated from 12 dead turkey embryos found in an SPF flock. SPF flocks are repeatedly tested (every 6 weeks) for the presence of any specific pathogens, including viruses and bacteria. The vitellus from each dead embryo was isolated and placed in FM4 medium. After $24 \mathrm{~h}$ of incubation, cultures were plated onto FM4 solid medium, and 1 day later medium-size colonies that did not have the typical fried-egg appearance (rounded without a central point) were observed. For each embryo, two colonies were

* Corresponding author. Mailing address: Laboratoire de Biologie Cellulaire et Moléculaire, INRA, 71 avenue Edouard-Bourleaux, B.P.81, 33883 Villenave d'Ornon Cedex, France. Phone: (33) 55684 31 50. Fax: (33) 5568431 59. E-mail: laigret@bordeaux.inra.fr. cloned three times with filtration through 450-nm-pore-size membrane filters between platings, as recommended by the Subcommittee on the Taxonomy of Mollicutes (12). One of the clones obtained was named strain 94254. Strain $95098 \mathrm{GC}$ was isolated from dead turkey embryos from a field flock by the same procedure.

Biochemical tests. Biochemical tests were performed as previously described (23). These tests included tests for digitonin sensitivity, glucose fermentation, arginine hydrolysis, tetrazolium salt reduction, phosphatase activity, film and spot production, and growth in the absence of NAD and L-cysteine.

Serologic tests. Dot immunoblotting was performed as previously described (26) by using Millititer filtration plates containing Durapore membranes (Millipore Corp., Milford, Mass.). The hyperimmune specific antisera were prepared by the procedure of Senterfit (28). Growth inhibition tests were performed with antiserum-saturated discs placed on FM4 plates inoculated by the running drop method (6)

SDS-PAGE of cellular proteins. Cells from 50-ml cultures of strains 94254 95098GC, and $90000, M$. pullorum $\mathrm{CKK}^{\mathrm{T}}, M$. gallinarum $\mathrm{PG}^{\mathrm{T}}{ }^{\mathrm{T}}, M$. gallinaceum $\mathrm{DD}^{\mathrm{T}}$, and $M$. gallisepticum ATCC 15302 were pelleted by centrifugation at $16,000 \times g$ for $30 \mathrm{~min}$ at $4^{\circ} \mathrm{C}$, washed with $25 \mathrm{ml}$ of $0.1 \mathrm{M} \mathrm{Na}_{2} \mathrm{PO}_{4}-0.33 \mathrm{M} \mathrm{NaCl}$ (pH 7.0), pelleted again, and suspended in $1 \mathrm{ml}$ of distilled water. The protein concentration was determined by the method of Lowry et al. (22) and was adjusted to $2 \mathrm{mg} / \mathrm{ml}$. One volume of a solution containing $2 \%$ sodium dodecyl sulfate (SDS), $15 \%$ glycerol, $5 \% \beta$-mercaptoethanol, and $0.1 \%$ bromophenol blue was added. Samples were boiled for $5 \mathrm{~min}$ and subjected to SDS-polyacrylamide gel electrophoresis (PAGE) for $18 \mathrm{~h}$ at $40 \mathrm{~V}$ in $12.5 \%$ polyacrylamide gels as described by Laemmli (20).

16S rRNA sequence determination. The 16S rRNA genes were enzymatically amplified from strains 94254 and $95098 \mathrm{GC}$ and $M$. pullorum $\mathrm{CKK}^{\mathrm{T}}$. The $\mathrm{PCR}$ assays were performed in final volumes of $50 \mu \mathrm{l}$, and each assay mixture contained $16.6 \mathrm{mM}\left(\mathrm{NH}_{4}\right)_{2} \mathrm{SO}_{4}, 67 \mathrm{mM}$ Tris-HCl (pH 8.0), $2 \mathrm{mM} \mathrm{MgCl} 2,0.001 \%$ anionic detergent, $4.4 \mu \mathrm{g}$ of bovine serum albumin per $\mathrm{ml}, 200 \mu \mathrm{M}$ dATP, 200 $\mu \mathrm{M}$ dTTP, $200 \mu \mathrm{M}$ dCTP, $200 \mu \mathrm{M}$ dGTP, each primer at a concentration of 1 $\mu \mathrm{M}, 0.5 \mathrm{U}$ of $T$ th DNA polymerase (MBI Fermentas, Vilnius, Lithuania), and 5 ng of genomic DNA. The PCR primers were the $\mathrm{fD} 1$ and $\mathrm{rP} 1$ oligonucleotides (30), which can be used to amplify the 16S rRNA genes of most eubacteria. PCR were performed in a programmable heating block (Perkin-Elmer Cetus Corp. Norwalk, Conn.) by using 40 cycles. Each cycle consisted of denaturation at $92^{\circ} \mathrm{C}$ for $20 \mathrm{~s}$, annealing of primers at $62^{\circ} \mathrm{C}$ for $20 \mathrm{~s}$, and extension at $72^{\circ} \mathrm{C}$ for $40 \mathrm{~s}$. The PCR products of the expected size $(1.5 \mathrm{~kb})$ were cloned into plasmid vector pGEM-T (Promega Biotech, Madison, Wis.) according to the manufacturer's instructions and were propagated in Escherichia coli XL1-Blue (Stratagene, La Jolla, Calif.) by using electroporation (9). For each mycoplasma strain, three recombinant plasmids were sequenced by using a T7 sequencing kit (Pharmacia Uppsala, Sweden) and universal forward and reverse sequencing primers, as well as three $16 \mathrm{~S}$ rRNA gene internal universal primers as described previously (21)

Phylogenetic analysis. A search for similarity to the 16S rRNA gene sequence of $M$. pullorum CKK $^{\mathrm{T}}$ was performed by using the SIMILARITY-RANK tool of the Ribosomal Databank Project (24) and the BLAST (2) and FASTA (32) software with data from the GenBank and EMBL databases. Alignment with the most similar sequences was performed by using the Pileup program of the Genetics Computer Group package (7), edited manually, and 1,331 nonambiguous positions were used to establish pairwise evolutionary distances as described by Jukes and Cantor (15). The DNADIST and FITCH programs from the PHYLIP 3.5 package (10) were used for dendrogram construction. The $M$ gallisepticum 16S rRNA sequence was used as an outgroup.

Pathogenicity studies. Pathogenicity studies were conducted with SPF chicken eggs or SPF turkey eggs. Twenty 7 -day-old embryonated eggs were inoculated via 


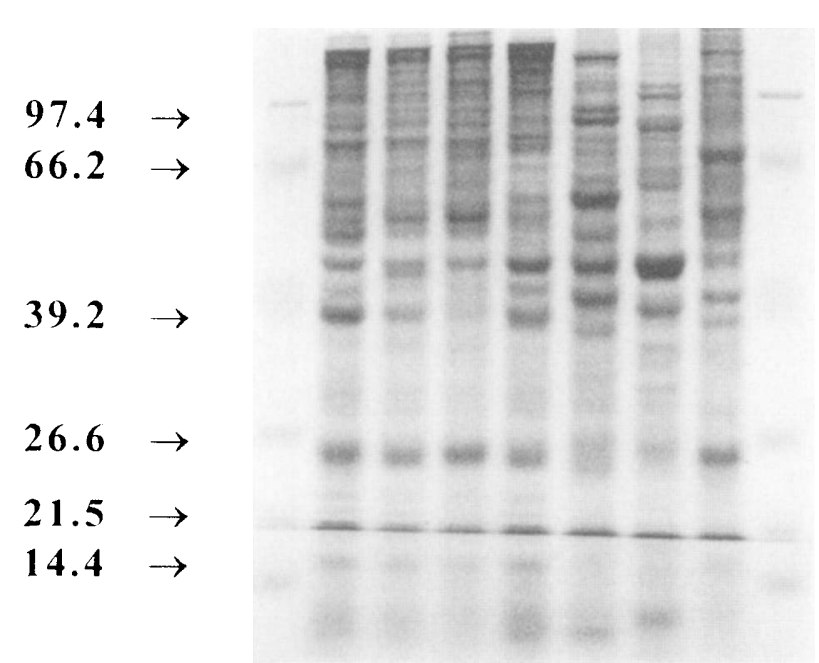

FIG. 1. SDS-PAGE of cellular proteins. Lane 1, M. pullorum $\mathrm{CKK}^{\mathrm{T}}$; lane 2, strain 94254; lane 3, strain 95098GC; lane 4, strain 90000; lane 5, M. gallinaceum $\mathrm{DD}^{\mathrm{T}}$; lane $6, M$. gallinarum $\mathrm{PG}^{\mathrm{T}}{ }^{\mathrm{T}}$; lane $7, M$. gallisepticum ATCC 15302 ; lanes $\mathrm{M}$, premixed protein molecular weight marker (Boehringer, Mannheim, Germany). The numbers on the left are molecular masses (in kilodaltons).

the yolk sac with $0.1-\mathrm{ml}$ portions of cultures of $M$. pullorum $\mathrm{CKK}^{\mathrm{T}}$ (SPF chicken and turkey eggs), strain 94254 (SPF chicken and turkey eggs), and strain 95098GC (SPF chicken eggs). For each strain, three dilutions were tested (approximately $10,10^{3}$, and $10^{5}$ color-changing units $[\mathrm{CCU}] / \mathrm{ml}$ ). A total of 40 7 -day-old embryonated eggs were inoculated with sterile medium and 20 other eggs were not inoculated as controls. The eggs were candled daily until the day 13 of incubation for chicken embryos or day 26 for turkey embryos. All of the dead and surviving embryos were examined for lesions and cultured for mycoplasmas.

Nucleotide sequence accession number. The 16S rRNA gene sequence of $M$. pullonim CKK $^{\mathrm{T}}$ has been assigned GenBank accession number U58504

\section{RESULTS AND DISCUSSION}

Cultural and biochemical properties. Strains 94254, and 95098GC and $M$. pullorum CKK $^{\mathrm{T}}$ exhibited identical cultural and biochemical properties. They grew in the absence of NAD and L-cysteine in culture medium. They were sensitive to $1.5 \%$ digitonin, fermented glucose, did not hydrolyze arginine, did not display phosphatase activity, did not reduce 2,3,5-tetrazolium choride, and did not produce films and spots. These results were consistent with the results of previous studies describing $M$. pullorum $\mathrm{CKK}^{\mathrm{T}}$ (14), but these properties are shared by $M$. gallinaceum.

Serologic tests. Dot immunobinding tests were performed with strains 94254 and $95098 \mathrm{GC}$ by using hyperimmune antisera prepared against the following avian mycoplasmas: $M$. pullorum, M. gallinaceum, $M$. anatis, $M$. glycophilum, M. gallopavonis, $M$. meleagridis, and $M$. iowae. A positive reaction was obtained only with anti- $M$. pullorum $\mathrm{CKK}^{\mathrm{T}}$ serum. Growth inhibition tests performed with antisera against $M$. pullorum, M. gallinaceum, M. gallisepticum, M. gallopavonis, M. glycophilum, $M$. columbinum, $M$. anatis, and $M$. synoviae gave similar results. The inhibition zone was $12 \mathrm{~mm}$ in diameter with anti-M. pullorum serum, and a similar value was obtained with antiserum to $M$. pullorum $\mathrm{CKK}^{\mathrm{T}}$.

Cellular protein analysis. The cellular protein patterns exhibited by $M$. pullorum $\mathrm{CKK}^{\mathrm{T}}$ and strains 94254 , 95098GC, 95068, and 90000 were almost identical to each other but clearly distinct from those of $M$. gallisepticum ATCC 15302, $M$. gallinarum PG16 ${ }^{\mathrm{T}}$, and M. meleagridis $17529^{\mathrm{T}}$ (Fig. 1). How- ever, they seemed to share some bands with the pattern of $M$. gallinaceum $\mathrm{DD}^{\mathrm{T}}$, a member of the Mycoplasma hominis phylogenetic group.

16S rRNA gene analysis and phylogenetic position of $M$. pullorum CKK ${ }^{\mathbf{T}}$. The nucleotide sequences of the 16S rRNA genes of strains 94254 and $95098 \mathrm{GC}$ and $M$. pullorum $\mathrm{CKK}^{\mathrm{T}}$ were identical. Phylogenetic analyses indicated that $M$. pullorum belongs to the $M$. hominis phylogenetic group (Fig. 2), which is clearly distinct from the Mycoplasma pneumoniae cluster containing $M$. gallisepticum and $M$. iowae (31). Within the $M$. hominis cluster, $M$. pullorum is part of a group containing four avian and two feline mycoplasmas (Mycoplasma corogypsi, Mycoplasma leocaptivus, Mycoplasma felis, Mycoplasma sturnidae, M. gallinaceum, and $M$. synoviae). Our results are consistent with those obtained by other workers $(4,5,25)$.

Pathogenicity studies. The kinetics of chicken embryo mortality after inoculation with strains 94254 and $95098 \mathrm{GC}$ and $M$. pullorum $\mathrm{CKK}^{\mathrm{T}}$ are shown in Fig. 3. The mortality of noninoculated eggs or eggs inoculated with sterile medium was less than $15 \%$ until day 13 of incubation (data not shown). The mortality values obtained with $M$. pullorum $\mathrm{CKK}^{\mathrm{T}}$ ranged from 30 to $65 \%$ depending on the number of CCU inoculated. With strain 94254 , the mortality reached $50 \%$ after 8 days regardless of the number of CCU inoculated. With strain $95098 \mathrm{GC}, 80$ to $100 \%$ mortality was obtained after 6 days. The levels of mortality were statistically significant; on the last day of incubation, the $\chi^{2}$ values were $4.43(P=0.04 \%)$ for eggs inoculated with strain $94254,30.6(P=0.00 \%)$ for eggs inoculated with strain 95098GC, and $12.5(P=0.00 \%)$ for eggs inoculated with $M$. pullorum $\mathrm{CKK}^{\mathrm{T}}$. The dead embryos from inoculated eggs were

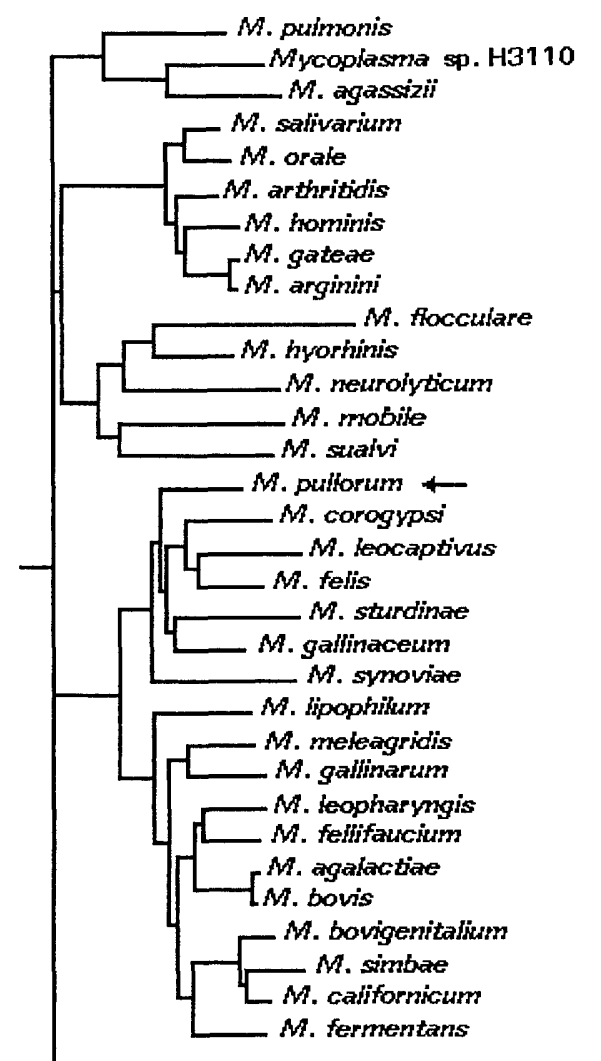

M. gallisepticum

FIG. 2. Phylogenetic tree of the $M$. hominis phylogenetic group, including $M$. pullorum. 

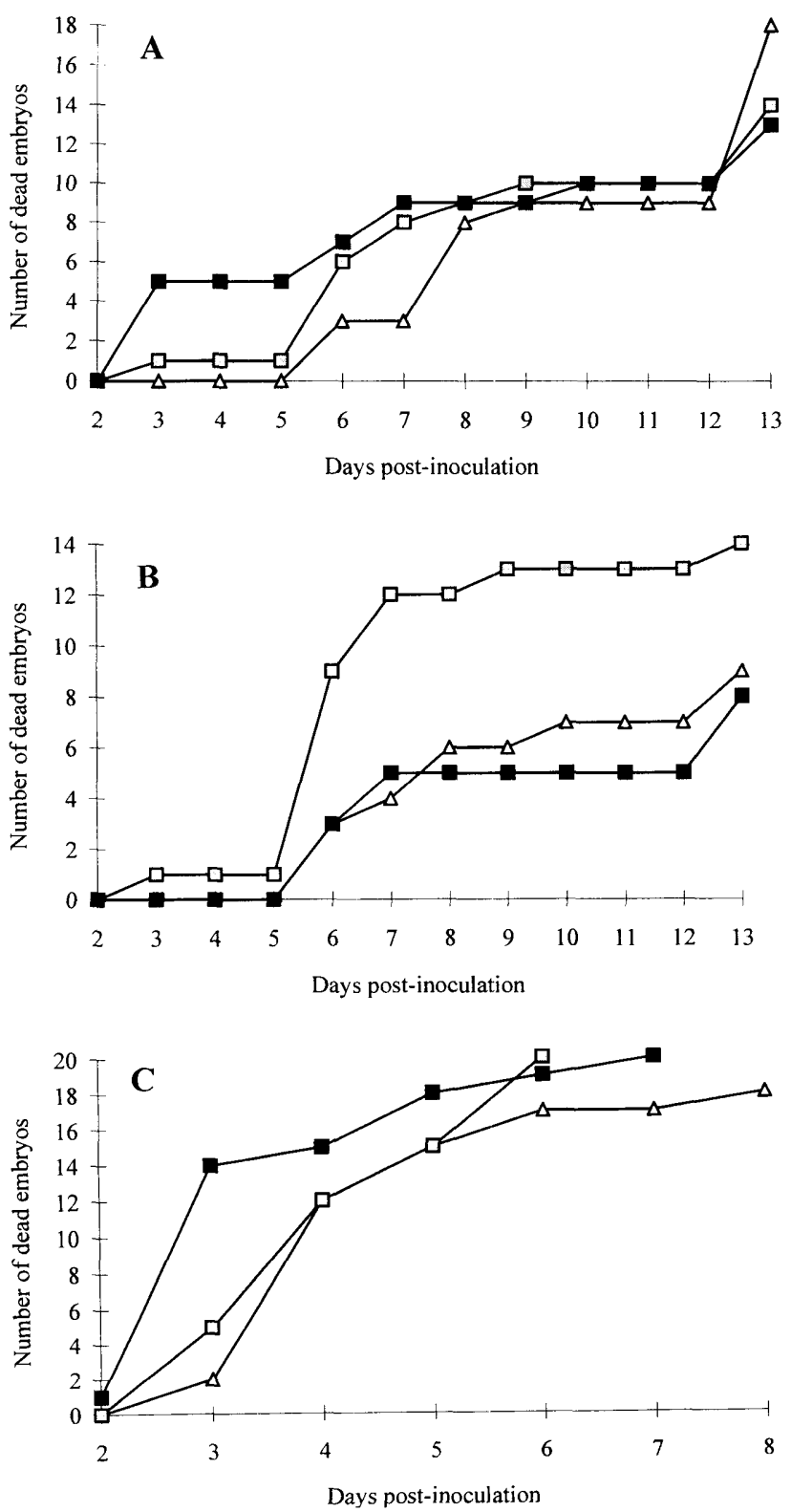

FIG. 3. Chicken embryo mortality following inoculation with strain 94254 (A), M. pullorum $\mathrm{CKK}^{\mathrm{T}}$ (B), and strain $95098 \mathrm{GC}$ (C). Symbols: open triangles, $10 \mathrm{CCU} / \mathrm{egg}$; light squares, $10^{3} \mathrm{CCU} / \mathrm{egg}$; dark squares, $10^{5} \mathrm{CCU} / \mathrm{egg}$.

dwarfed. With turkey eggs, 30 and $70 \%$ mortality with $M$. pullorum $\mathrm{CKK}^{\mathrm{T}}$ and strain 94254 , respectively, was observed on day 19 of incubation (data not shown). Because it was not possible to hatch injected eggs, we decided to stop the incubation on day 26 . This may have reduced the level of mortality that would have been obtained if eggs had been incubated until they hatched, as under field conditions. Indeed, in $M$. pullorum-infected flocks, embryo mortality is usually observed during the last days of incubation. Mycoplasmas that had biochemical properties of $M$. pullorum could be cultured from dead embryo vitellus.

Conclusions. The results presented here demonstrate that mycoplasma strains 94254 and $95098 \mathrm{GC}$, which were isolated from SPF and field turkey flocks, respectively, belong to the species $M$. pullorum. Until now, $M$. pullorum was not identified as pathogenic and had never been isolated from dead turkey embryos. Avian serotype $\mathrm{C}$ and $\mathrm{O}$ mycoplasmas, later naned $M$. pullorum (14), have been isolated from chickens, quails, partridges, and pheasants $(1,3,17,19,27,29,33,35)$. Previous pathogenicity experiments did not clearly show if $M$. pullorum was pathogenic $(8,18,35)$. From our data it seems that the embryo mortality observed is significant. Other mycoplasma strains having biochemical and serologic characteristics of $M$. pullorum have recently been isolated in France from adult turkeys and dead turkey embryos (16). Thus, the incidence of infection by $M$. pullorum and the pathogenicities of the different strains need to be studied in more detail.

\section{REFERENCES}

1. Adler, H. E., J. Fabricant, R. Yamamoto, and J. Berg. 1958. Isolation and identification of pleuro-pneumoniae-like organisms of avian origin. Am. J. Vet. Res. 19:440-447.

2. Altshul, S. F., W. Gish, W. Miller, E. W. Myers, and D. J. Lipman. 1990 Basic local alignment search tool. J. Mol. Biol. 215:403-410.

3. Bencina, D., D. Dorrer, and T. Tadina. 1987. Mycoplasma species isolated from six avian species. Avian Pathol. 16:653-664

4. Boyle, J. S., and C. J. Morrow. 1994. Phylogeny of avian mycoplasmas: implications for mollicute taxonomy. IOM Lett. 3:589-590.

5. Brown, D. R., G. S. McLaughlin, and M. B. Brown. 1995. Taxonomy of the feline mycoplasmas Mycoplasma felifaucium, Mycoplasma feliminutum, $M y$ coplasma felis, Mycoplasma gateae, Mycoplasma leocaptivus, Mycoplasma leopharyngis, and Mycoplasma simbae by $16 \mathrm{~S}$ rRNA gene sequence comparisons. Int. J. Syst. Bacteriol. 45:560-564.

6. Clyde, W. A. 1983. Growth inhibition tests, p. 405-410. In S. Razin and J. G. Tully (ed.), Methods in mycoplasmology, vol. 1. Academic Press, Inc., New York, N.Y.

7. Devereux, J., P. Haeberli, and O. Smithies. 1984. A comprehensive set of sequence analysis programs for the VAX. Nucleic Acids Res. 12:387-395.

8. Dierks, R. E., J. A. Newman, and B. S. Pomeroy. 1967. Characterization of avian mycoplasma. Ann. N.Y. Acad. Sci. 143:170-189.

9. Dower, W. J., J. F. Miller, and C. W. Ragsdale. 1988. High efficiency transformation of $E$. coli by high voltage electroporation. Nucleic Acids Res. 16:6127-6145

10. Felsenstein, J. 1989. PHYLIP-phylogeny inference package (version 3.2) Cladistics 5:164-166.

11. Frey, M. L., R. P. Hanson, and D. P. Anderson. 1968. A medium for isolation of avian mycoplasmas. Am. J. Vet. Res. 29:2163-2171.

12. International Committee on Systematic Bacteriology Subcommittee on the Taxonomy of Mollicutes. 1995. Revised minimum standards for the description of new species of the class Mollicutes (division Tenericutes). Int. J. Syst. Bacteriol. 45:605-612.

13. Jordan, F. T. W. 1979. Avian mycoplasma, p. 1-48. In J. G. Tully and R. F. Whitcomb (ed.), The mycoplasmas, vol. II. Academic Press, Inc., New York, N.Y.

14. Jordan, F. T. W., H. Ernø, G. S. Cottew, K. H. Hinz, and L. Stipkovits. 1982. Characterization and taxonomic description of five mycoplasma serovars (serotypes) of avian origin and their elevation to species rank and further evaluation of the taxonomic status of Mycoplasma synoviae. Int. J. Syst. Bacteriol. 32:108-115.

15. Jukes, T. H., and C. R. Cantor. 1969. Evolution of protein molecules, p. 21-132. In H. N. Munro (ed.), Mammalian protein metabolism. Academic Press, Inc., New York, N.Y.

16. Kempf, I. Unpublished data.

17. Kempf, I., F. Gesbert, E. Guinebert, M. Guittet, and G. Bennejean. 1991. Isolement et caractérisation d'une souche mycoplasmique chez des faisans d'élevage. Rcl. Med. Vet. 167:1133-1139.

18. Kleckner, A. L. 1960. Serotypes of avian pleuro-pneumoniae like organisms. Am. J. Vet. Res. 21:274-280.

19. Koshimizu, K., T. Magaribuchi, K. Tanabe, and N. Kono. 1978. Isolation and characterization of mycoplasmas from gallinaceous birds. Jpn. J. Vet. Sci. 40:445-449.

20. Laemmli, U. K. 1970. Cleavage of structural proteins during the assembly of the head bacteriophage T4. Nature 227:680-685.

21. Lane, D. J., B. Pace, G. J. Olsen, D. A. Stahl, M. L. Sogin, and N. R. Pace. 1985. Rapid determination of $16 \mathrm{~S}$ ribosomal RNA sequences for phylogenetic analyses. Proc. Natl. Acad. Sci. USA 82:6955-6959.

22. Lowry, O. H., N. J. Rosebrough, A. L. Farr, and N. J. Randall. 1951. Protein measurement with the Folin phenol reagent. J. Biol. Chem. 13:265-275.

23. Nougayrede, P., G. Gaillard-Perrin, and B. Andral. 1985. Apport du laboratoire pour le diagnostic des mycoplasmoses majeures de la dinde. Point Vet. 17:127-140.

24. Olsen, G. J., N. Larsen, and C. R. Woese. 1991. The Ribosomal RNA Database Project. Nucleic Acids Res. 19:2017-2021.

25. Panangala, V. S., J. S. Stringfellow, K. Dybvig, A. Woodard, F. Sun, D. L. 
Rose, and M. M. Gresham. 1993. Mycoplasma corogypsi sp. nov., a new species from the footpad abscess of a black vulture, Coragyps atratus. Int. J. Syst. Bacteriol. 43:585-590.

26. Poumarat, F., B. Perrin, and D. Longchambon. 1991. Identification of ruminant mycoplasmas by dot immunobinding on membrane filtration (MF Dot). Vet. Microbiol. 29:329-338.

27. Poveda, J. B., J. Carranza, A. Miranda, A. Garrido, M. Hermoso, M. Fernandez, and J. Domenech. 1990. An epizootiological study of avian mycoplasmas in southern Spain. Avian Pathol. 19:627-633.

28. Senterfit, L. B. 1983. Preparation of antigens and antisera, p. 401-404. In S. Razin and J. G. Tully (ed.), Methods in mycoplasmology, vol. 1. Academic Press, Inc., New York, N.Y.

29. Shimizu, T., K. Numano, and K. Uchida. 1979. Isolation and identification of mycoplasma from various birds: an ecological study. Jpn. J. Vet. Sci. 41:273282.
30. Weisburg, W. G., S. M. Barns, D. A. Pelletier, and D. J. Lane. 1991. 16S ribosomal DNA amplification for phylogenetic study. J. Bacteriol. 173:697703.

31. Weisburg, W. G., J. G. Tully, D. L. Rose, J. P. Petzel, H. Oyaizu, D. Yang, L. Mandelco, J. Sechrest, T. G. Lawrence, J. Van Etten, J. Maniloff, and C. R. Woese. 1989. A phylogenetic analysis of the mycoplasmas: basis for their classification. J. Bacteriol. 171:6455-6467.

32. Wilbur, W. J., and D. J. Lipman. 1983. Rapid similarity searches of nucleic acid and protein data banks. Proc. Natl. Acad. Sci. USA 80:726-730.

33. Yamamoto, R., and H. R. Adler. 1958. Characterization of pleuro-pneumoniae-like organisms of avian origin. J. Infect. Dis. 102:243-250.

34. Yoder, H. W., and M. S. Hofstad. 1962. A previously unreported serotype of avian mycoplasma. Avian Dis. 6:147-160.

35. Yoder, H. W., and M. S. Hofstad. 1964. Characterization of avian mycoplasma. Avian Dis. 8:481-512. 